\title{
Labyrinthe
}

$2 \mid 1999$

Numéro 2

\section{Violence symbolique d'Etat contre violence terroriste basque}

\section{Xavier Crettiez}

\section{(2) OpenEdition \\ 12 Journals}

\section{Electronic version}

URL: http://journals.openedition.org/labyrinthe/360

DOI: $10.4000 /$ labyrinthe. 360

ISSN: 1950-6031

\section{Publisher}

Hermann

\section{Printed version}

Date of publication: 15 January 1999

Number of pages: 59-75

\section{Electronic reference}

Xavier Crettiez, «Violence symbolique d'Etat contre violence terroriste basque », Labyrinthe [Online],

2 | 1999, Online since 04 March 2005, connection on 20 April 2019. URL : http://

journals.openedition.org/labyrinthe/360 ; DOI : 10.4000/labyrinthe.360

This text was automatically generated on 20 April 2019.

Propriété intellectuelle 
Violence symbolique d'Etat contre violence terroriste basque

\author{
Xavier Crettiez
}

